\title{
University Education in Digital Humanities for Information Professionals
}

\author{
Anna Kamińska \\ ORCID 0000-0002-2778-6694 \\ Department of Information Studies, \\ Faculty of Journalism, Information and Book Studies \\ University of Warsaw
}

\begin{abstract}
Purpose/Thesis: The article presents the concept of university course in digital humanities for future information professionals.

Approach/Methods: The concept of university course in digital humanities draws on the author's deep knowledge of digital humanities as well as the particular models of research project lifecycle. The concept consists of three elements: the description of educational aims, the graduate's profile, and the learning outcomes.

Results and conclusions: The author proposes that university course in digital humanities should be provided as a part of specialization within a Master program for information professionals. Classes will give students a basic knowledge of a given discipline in the humanities and the theoretical aspects of digital humanities, as well as its structure and history. Students will also learn about information and knowledge organization, digital sources used in humanities, information systems, digital collections, research data management, and scholarly editions. Graduates would be equipped to work at research institutions running digital humanities projects or providing research infrastructure for digital humanists, e.g. academic libraries, museums, archives, digital humanities centers and laboratories. Practical implications: The concept may be used to prepare a detailed program of specialization by faculties offering information science programs. Although the concept has been developed in the context of Polish higher education, it can be modified and adapted successfully in other countries, especially in the EU countries which, like Poland, need to meet the European Qualifications Framework.

Originality/Value: Formal university course in digital humanities for information professionals is not very common. The concept of a specialization within a Master program proposed in this article fills this gap so that a new generation of librarians and other information professionals will become more proficient intermediaries between humanists and information.
\end{abstract}

\section{Keywords}

Academic programs. Digital humanities. Information professionals. Information science. Information studies. Librarians. University education.

Received: 30 July 2021. Reviewed: 31 October 2021. Revised: 25 November 2021. Accepted: 17 December 2021.

\section{Introduction}

The purpose of this article is to present the concept of university education in the digital humanities for information professionals. The author formulated the concept of 
a specialization within a Master (MA) program for information professionals in digital humanities, which consists of the description of educational aims, the graduate's profile, and learning outcomes.

The role of information professionals, particularly librarians, in the development of digital humanities has been described quite widely in the literature (see Hartsell-Gundy et al., 2015; Lee, 2017; Sula, 2013; White \& Gilbert, 2016; Wilson, 2020). Research shows that information professionals are involved in preparing infrastructure such as digital collections, databases, or ontologies, which are used by digital humanists to conduct their research. Information professionals also take part in digital humanities projects as specialists, intermediaries between humanities researchers and IT center, or project leaders. Additionally, they typically teach humanists interested in digital collection, research data management, or information and knowledge organization by offering workshops or academic courses. Information professionals are present in digital humanities centers, university digital humanities networks, or international consortia like DARIAH ${ }^{1}$. Research and academic libraries also play a crucial role in making humanities research digital. The libraries offer particular services, tools, devices, or space for research. They might constitute an independent unit involved in digital humanities or a part of a university digital humanities network (Maron \& Pickle, 2014).

However, it seems that information professionals still have too narrow knowledge and skills in digital humanities to engage in this field successfully (see LIBER, 2019). University education might be a solution to this problem.

As short-term workshops or professional courses would most typically not give enough insight into the broad and complex field of digital humanities; information professionals could acquire comprehensive knowledge and skills in this field thanks to tailored university education programs. University education in digital humanities could also provide a sustainable increase in the number of information professionals ready to cooperate with digital humanists effectively. The new generation of librarians and other information professionals would become more proficient intermediaries between humanists and information.

Formal university education of information professionals in digital humanities has not proved to be very common. The study on university education of information professionals in digital humanities revealed that 12 academic programs were offered in 2019 in the English language (Kamińska, 2020). The collected sample of academic programs did not constitute the whole academic programs in digital humanities offered to information professionals around the world, thus it seems rather impossible to generalize the study results. However, a qualitative analysis of the collected academic programs may offer some interesting solutions for the preparation of this kind of academic course.

The sample comprised five programs from the United States, five programs from Great Britain, one program from Israel, and one from Canada. Most of these programs were offered for MA students, rarely for PhD candidates. MA students were typically learning about practical aspects of digital humanities as they could make humanities research digital, whereas $\mathrm{PhD}$ candidates were typically learning methodological aspects of digital

1 The Digital Research Infrastructure for the Arts and Humanities (DARIAH) is an European consortium developing and offering digital resources, tools and technologies to conduct research in Arts and Humanities (https://www.dariah.eu/). 
humanities to investigate information science research. The programs had different forms of organization: a degree program, a specialization, diploma studies, or an advanced certificate. The form of program organization affected the number of modules necessary to complete it, for example, the advanced certificate consisted of four modules. The specialization offered by the Indiana University Bloomington Department of Information \& Library Science (United States) encompassed six or seven modules ${ }^{2}$ (https://ils.indiana.edu/programs/specializations/digital-humanities.html). The largest number of modules was demanded within a degree program and diploma studies. The MA program offered by the School of Library and Information Studies of the University of Alberta (Canada) consisted of 15 modules and lasted three years (https://www.ualberta.ca/school-of-library-and-information-studies/ programs/mamlis) whereas the MA program ${ }^{3}$ offered by the Department of Information Studies of the University College London (United Kingdom) comprised eight modules and lasted one year (a full-time program) or two years (a part-time program) (https://www.ucl. ac.uk/information-studies/study/postgraduate-study/mamsc-digitalhumanities).

In almost all cases, the programs offered the students a certain level of flexibility as there were several optional modules to choose from. The compulsory modules mostly concerned: 1) introduction to digital humanities, 2) digital humanities projects, 3) digital humanities technologies, 4) project management, 5) digital sources for humanities, 6) information organization, 7) information services, 8) introduction to library and information science (LIS), and 9) LIS methodology.

The optional modules included a variety of topics and could be divided into three groups. The group of subjects not connected with new technologies contained the history of books, intellectual property protection, or management. The subjects such as programing, data mining, creation of databases, creation of commuter games, and 3D animations were classified into the group of modules strongly connected with new technologies. The group of subjects constituted the intersection of humanities, social sciences, and new technologies, concerned mostly the fields of information science such as information and knowledge organization, data management, digital collections, information architecture, information systems, or scholarly communication.

Faculties teaching digital humanities programs for information professionals quite frequently cooperated with teachers and researchers from humanities faculties who teach particular courses and help students prepare their theses (Kamińska, 2020).

The study on university education in digital humanities for information professionals in Poland showed that in 2019 there was no degree program or specialization in digital humanities offered for information professionals (Kamińska, 2020).

To fill this gap, the concept of a specialization within a MA program for information professionals in digital humanities was proposed by the author of this article. Although the concept of the course follows the Polish context of higher education, it can be modified and adapted successfully in other countries, especially in the EU countries which, like Poland, need to meet the European Qualifications Framework.

${ }^{2}$ Participants of this program needed to gain a particular number of credits. Compulsory modules had a different number of credits, therefore the number of modules necessary to complete the program depended on chosen compulsory modules.

${ }^{3}$ In the form of a degree program or diploma studies. 


\section{Methodology}

Two equivalent elements were used to create the concept of university education in digital humanities for information professionals. These are the comprehensive picture of digital humanities and the model of research project lifecycle.

The comprehensive picture of digital humanities constituted the basis to describe the aims of university education in digital humanities for information professionals as well as to indicate learning outcomes (knowledge, skills, and social competences) necessary to work in digital humanities.

The digital humanities consists of many fields of interest. From the perspective of this article, the theory of digital humanities (definitions, characteristics, directions of development), the practice of doing digital humanities projects, the organization of digital humanities, and university education in digital humanities seem to be most important.

Knowledge of the theory of digital humanities might be helpful in indicating social competences, which information professionals need to gain. It might also be useful to determine particular soft skills necessary to work in digital humanities. The organization of digital humanities turns out to be important to choose particular social competences, soft skills, and fields of knowledge, which need to be taught within university education of information professionals. It also indicates institutions where information professionals with digital humanities skills might find a place to work. The knowledge of the practice of doing digital humanities projects helps to determine fields of knowledge and particular hard skills, which constitute the basis of digital humanities. The picture of university education programs in digital humanities might be useful in indicating particular fields of knowledge and hard skills in digital humanities, too.

The doctoral thesis Cyfrowa humanistyka - koncepcja, kierunki i stan rozwoju oraz powiazania $z$ informatologia (Eng. The Concept and the Current State of Development of Digital Humanities as Well as the Relationship Between Digital Humanities and Information Science) by Anna Kamińska (2020) comprises the main source of information on digital humanities based on. English and Polish literature, as well as a doctoral research project. The description of definitions and characteristics of digital humanities was based on the qualitative discourse analysis of American and Polish scholarly literature. The organization of digital humanities was presented based on the analysis of secondary resources (desk research method) of English and Polish literature as well as the case study of organization of digital humanities in the United Kingdom, Ireland, and Poland. The analysis of abstracts from the books of abstracts of the International Annual Conference "Digital Humanities" from 2016-2018, organized by the Alliance of Digital Humanities Organizations gave a picture of the practice of digital humanities projects and its fields of interest. The investigation of courses within academic programs in digital humanities in the United Kingdom, Ireland, and Poland allowed to learn about fields of knowledge, and skills needed for working in digital humanities. The main results of the doctoral research are presented below.

The definition of digital humanities was analyzed by American and Polish scholars. These two groups of scholars define the digital humanities differently. American scholars mostly define digital humanities as a separate discipline or field of humanities which uses new technologies to conduct research. Polish scholars usually define digital humanities as a model of conducting humanities research based on the usage of new technologies. 
American and Polish scholars agree that one of the main features of digital humanities is the use of new technologies to conduct humanities research. When it comes to other characteristics, they differ in their opinions and indicate features of digital humanities like diversity, interdisciplinarity, openness, or team work.

The analysis of Polish and English scholarly literature, as well as Polish and English web pages showed a great diversity of forms in digital humanities organization and provided the following forms: 1) academic units, 2) research institute units, 3) formal scientific networks, 4) museums and archives, 5) scientific societies and associations, 6) scholarly journals, 7) scientific conferences, 8) institutions financially supporting digital humanities research, and 9) scholarly social networks. It is very common for particular organizational structures of digital humanities to do the same tasks connected with digitalization of humanities research. Thus, the boundaries between the particular forms of organizations are not very clear.

The variety of forms of digital humanities organization was confirmed in the multiple case study research of Polish, Irish, and British digital humanities organizations. Some characteristic features of the organization of digital humanities in particular countries were noticed, with the main feature of the Polish digital humanities organization being the broad participation of academic libraries in this area. The primary feature of the Irish digital humanities organization is a significant number of academic courses. In contrast, its British counterpart offers a network model of organization of digital humanities.

Today, the most often digitized step of humanities research is the digitalization of research references, probably because of the availability of well-developed technology. Another reason is that this phase is necessary to digitize another step of humanities research, which is the analysis of research references by computer programs. Digital humanists often prepare digital collections of documents (such as books, photographs, or audiovisual records), databases with raw data, or digital scholarly editions.

The step of analyzing research references with computer programs is also well developed, although the level of development depends on the humanities discipline. Linguists as well as literary scholars are equipped with various computer programs assisting in conducting research. Text mining research has a long tradition. However, the number of computer programs that analyze pictures and sounds is still unsatisfactory.

Research results have been published in a digital form (such as in digital journals or repositories) for a long time, which may explain why digital humanists are not genuinely interested in this step of humanities research. A new form of digital scholarly publication has appeared, which is a kind of multimedia publication such as a web page, a 3D animation, or a movie of sorts.

Academic courses of digital humanities in Poland, Ireland, and the United Kingdom prove the main interests of digital humanists. A graduate of these courses usually can prepare databases or digital collections for humanities research, analyze digital research references with computer programs, and prepare research results in a digital text form.

A research project seems to be the most typical way to make humanities research digital. Therefore, a model of research project lifecycle was chosen to complete the information on digital humanities skills and to create the concept of university education in digital humanities for information professionals. Among the different models of the life cycle of the research project, the models by Nancy Maron and Sarah Pickle (2014) and Alessandro Sarretta (Minelli et al., 2018) were chosen and applied in this study. 
The model by Maron and Pickle encompasses the research projects on the preparation of digital research references for humanities research, or the creation of special computer tools for the analysis of this kind of research references. For instance, the projects could consist of creating digital collections, databases, content mapping tools, or data visualization tools. This model was elaborated for research on the organization of digital humanities at universities in the United States.

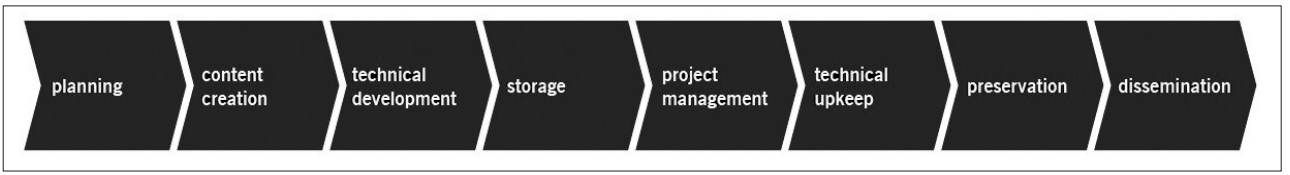

Fig. 1. The model of research project lifecycle by Nancy Maron and Sarah Pickle (2014)

The model encompasses eight stages (see Fig. 1), although the order of particular stages can be different than this proposed by Maron and Pickle. The first step concerns the project planning. The next one focuses on content creation, i.e. preparation of digital research references with digitalization or creation of original born-digital scholarship. The third stage, called technical development consists of creating computer tools to analyze digital research references. The next steps concern data storage, project management, and technical upkeep. The last stages are the long-term preservation of digital research references and the dissemination of computer tools and digital research references (Maron \& Pickle, 2014).

The model of research project lifecycle by Maron and Pickle does not encompass projects of research references analysis. Therefore, the model of research project lifecycle by Alessandro Sarretta was used to achieve a comprehensive picture in digital humanities project lifecycle. The model was proposed within the EcoNAOS project (Ecological Northern Adriatic Open Science Observatory System) (see Fig. 2), which concerned open science standards in the work of a marine ecological observatory in the Northern Adriatic Sea (NAS). The model combines elements of the research data life cycle and the traditional research project life cycle. Furthermore, it underscores the role of scientific communication in research projects (Minelli et al., 2018). Although Sarreta's model was created in the context of natural sciences, it can also be used in the context of digital humanities since it includes two important aspects of digital humanities, which are data management and open science.

The models of the research project lifecycle by Maron and Pickle and by Sarreta were used to indicate particular knowledge fields and hard skills, which allows information professionals to engage deeply in digital humanities projects.

The concept of university education in digital humanities for information professionals presented in this article consists of three elements. These are: 1) educational aims, 2) graduate's profile, and 3) learning outcomes. Educational goals and graduate's profile determine the vision and directions of education of information professionals in digital humanities. Learning outcomes (divided into knowledge, skills, and social competences) allow to choose subjects, which need to be taught within this specialization.

The concept excludes elements such as the choice of particular courses, teaching methods, evaluation methods, and the number of hours of the course, because they constitute elements of a program, not a concept of university education. Without these elements, the 
concept of university education of information professionals in digital humanities becomes more flexible and it is easier to prepare a detailed specialization course for faculties teaching information professionals.

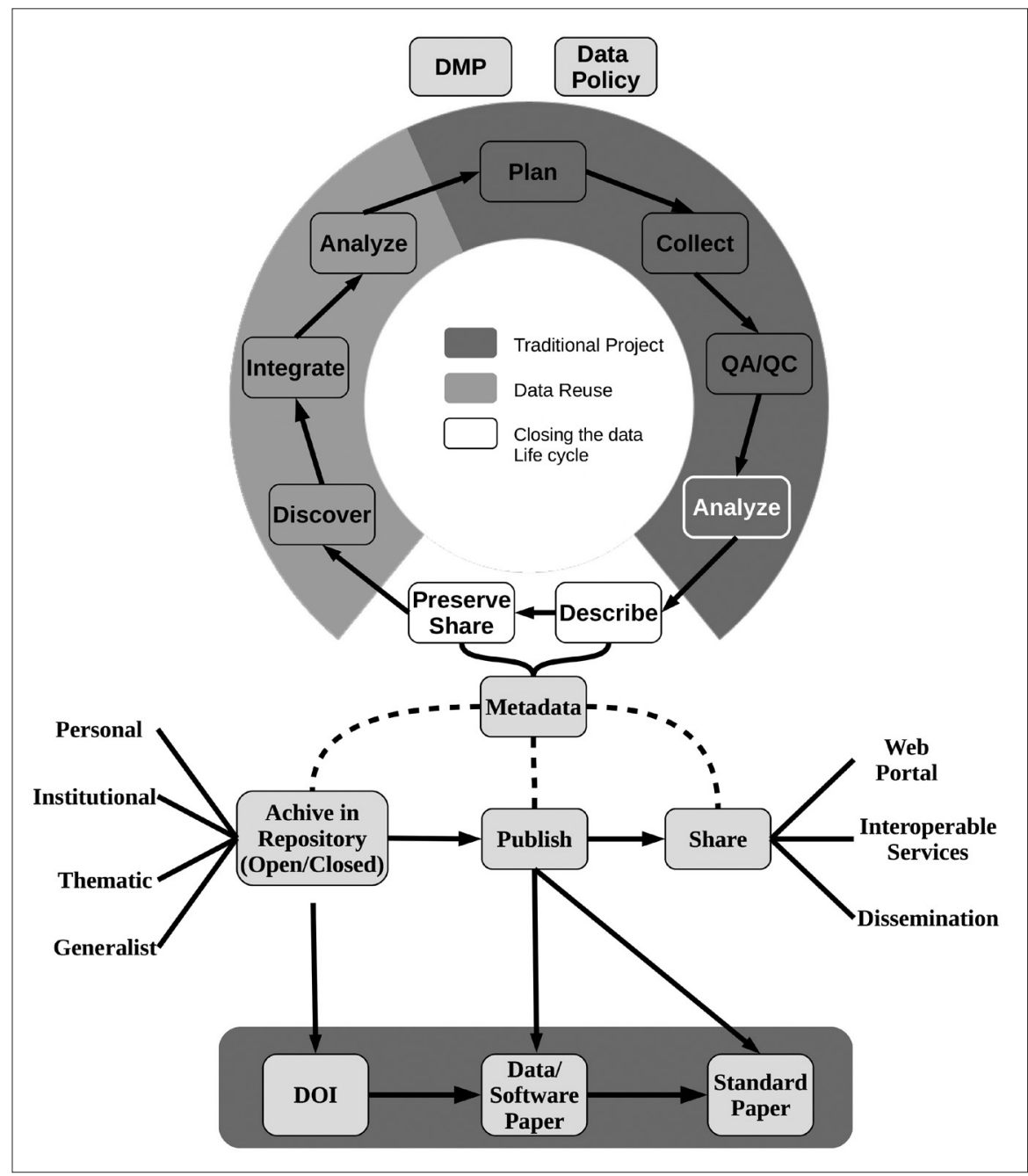

Fig. 2. The models of the research project lifecycle by Alessandro Sarretta (Minelli et al., 2018)

Learning outcomes are consistent with the qualifications of the Polish Qualifications Framework, level 7. The qualifications were described in the regulation of the Ministry of Science and Higher Education on the second level of characteristics of learning outcomes from the Polish Qualifications Framework levels 6-8, 14 November 2018 (Pol. Rozporządzenie Ministra Nauki i Szkolnictwa Wyższego z dnia 14 listopada 2018 r. w sprawie charakterystyk drugiego stopnia efektów uczenia się dla kwalifikacji na poziomach 6-8 Polskiej Ramy Kwalifikacji) (MNSW, 2018). 


\section{Presentation of the concept}

\subsection{General assumptions}

The concept of university education of information professionals in digital humanities is presented in a form of specialization within a MA program for information professionals called "Digital humanities".

Based on scientific research, this solution seemed to be the best one to prepare information professionals to work in digital humanities since the number of knowledge fields and skills needed to work in digital humanities is high. The specialization can encompass all these fields in, unlike a single course or module. Additionally, the assumption is that not everyone studying information science might be interested in working in digital humanities in the future; therefore, information science students should have a choice of specialization.

The specialization is proposed within the MA program because specializations are offered frequently within MA program in accordance with the Polish practice of teaching information science programs. It may be explained by the fact that Bachelor (BA) programs give students the basis in information science, whereas MA programs allow them to get insight into a particular field of information science and develop skills acquired within a BA course. For many Polish students, a MA program is also a moment when they decide which occupation they would like to find and discover which qualifications are necessary in their future work.

Basic knowledge and skills in information science are fundamental for information professionals who want to work in the digital humanities. The fields of information science such as the creation of digital collections, the information and knowledge organization, or the data management in humanities constitute important elements of digital humanities. A MA course will give future information professionals the opportunity to develop and acquire proficient skills in these fields. Additionally, students will build new knowledge and learn new skills in different fields on the basis of knowledge and skills obtained within a BA degree program.

\subsection{Educational goals}

The purpose of the specialization "Digital humanities" for MA students of information science is to:

- prepare students to conduct their own research projects at the intersection of information science and digital humanities;

- prepare students to work as information professionals in digital humanities. Students will make humanities research digital. They will be capable of working in different kinds of digital humanities institutions, e.g. academic libraries, museums, archives, research centers, and laboratories, especially digital humanities centers and laboratories;

- prepare students to continue academic education at the third level of university education. 


\subsection{Graduate's profile}

The role of the specialization "Digital humanities" for MA students in information science is to prepare future information specialists to actively participate in digital humanities projects. After completing the specialization, students will have proficient information and computer skills needed to work with data and information in digital environment. They will also have an in-depth knowledge on a particular humanities discipline, which will allow them to participate in digital humanities projects successfully. The projects will cover the preparation of digital research references, the analysis of this kind of research references, and the publication of research results in a digital form.

Graduates of the specialization "Digital humanities" will play a crucial role in mediation between digital humanists and data, information, and knowledge. They can cooperate as consultants with individual researchers, research teams, and organizations working on digital humanities. Graduates will also take part in digital humanities projects as members or leaders of research teams. They will be prepared to work in research institutions that provide the research infrastructure for digital humanities. For example, they will be able to coordinate the information processes of a particular research infrastructure. The specialization will give graduates competences which will allow them to participate in existing digital humanities projects or to initiate their own projects. Graduates can teach students and scholars particular aspects of digital humanities during professional workshops or academic courses.

Courses within the specialization "Digital humanities" will provide students with a basic knowledge on particularity of humanities discipline, the theoretical aspects of digital humanities, its organization and the context of appearance. Students will also learn about information and knowledge organization as well as digital sources used in humanities, such as digital collections, databases, or specialized catalogs. They will also acquire skills in the creation of advanced information systems and digital collections. Students will learn about strategies, techniques, and tools to work with data, namely how to gather, describe, organize, and visualize data. They will be able to publish research articles in a multimedia form, e.g. as a website or a computer animation.

The specialization "Digital humanities" will be offered to graduates of a BA program in information science as well as information professionals who would like to broaden their knowledge in digital humanities. The specialization can be interesting for graduates of humanities programs who would like to learn more on how to prepare digital research references or publish research results in a digital form. However, it will not equip them with the skills necessary for advanced data mining.

Graduates of the specialization "Digital humanities" can find job in research institutions, which develop digital humanities projects or provide research infrastructure for digital humanists. For instance, they can work in academic libraries, museums, archives, research centers and laboratories, especially in digital humanities centers and laboratories.

\subsection{Learning outcomes}

Learning outcomes are divided into three parts: knowledge, skills, and social competences. The description of each part contains the learning outcome code according to the Polish 
Qualification Framework (Pol. Rozporządzenie Ministra Nauki i Szkolnictwa Wyższego z dnia 14 listopada 2018 r. w sprawie charakterystyk drugiego stopnia efektów uczenia się dla kwalifikacji na poziomach 6-8 Polskiej Ramy Kwalifikacji) (MNSW, 2018).

(1) Knowledge

The graduate of the specialization "Digital humanities" knows:

- definitions, concepts, fields, directions of development, organization, and the most important institutions of digital humanities (P7S_WG);

- the basis of a particular humanities discipline which allows her/him to cooperate with humanists (P7S_WG);

- social, economic, political, and ethical aspects of the use of new technologies in the humanities (P7S_WK);

- relationships between digital humanities and information science (P7S_WG);

- terminology, theory, and methodology of information systems, digital collections, information architecture, information and knowledge organization, user studies, bibliometrics, altmetrics and informetrics at advanced level (P7S_WG);

- digital information sources for humanities (e.g. databases, digital collections, catalogues) at advanced level (P7S_WG);

- specialized tools for management of research references - for finding, collecting, storing, analyzing, and sharing research references (P7S_WG);

- specialized tools for management of research results - for visualization, presentation, and sharing research results (P7S_WG);

- channels of advanced digital scientific communication (P7S_WG);

- basis of research project management as well as sources of endowment for the humanities (P7S_WK);

- strategies and methods of promotion of science and GLAM institutions (P7S_WK);

- strategies and teaching methods (P7S_WG).

(2) Skills

A graduate of the specialization "Digital humanities" can:

- use acquired knowledge on the theoretical basis of digital humanities as well as information systems, digital collections, information architecture, information and knowledge organization, user studies, bibliometrics, altmetrics, and informetrics to solve research problems and to fulfil professional duties (P7S_UW);

- create and manage advanced information systems (P7S_UW);

- create and manage digital collections (P7S_UW);

- create network knowledge organization systems (P7S_UW);

- create the information architecture of websites and information systems (P7S_UW);

- collect, analyze, and interpret data on information behavior of digital humanists (P7S_UW);

- create different kinds of multimedia, e.g. websites, ebooks, movies, animations, or audio records (P7S_UW);

- plan processes of data management in humanities research (P7S_UW);

- find, collect, store, analyze, visualize, and share data and information of humanities research projects with specialized tools (P7S_UW);

- create simple computer programs on the basis of IT solutions at the elementary level (P7S_UW); 
- organize workshops, classes, and courses on digital humanities (P7S_UK);

- speak foreign language at the B2 level according to the Common European Framework of Reference for Languages (P7S_UK);

- work in a team as a member and a leader (P7S_UO);

- acquire new knowledge and skills in the digital humanities on her/his own initiative (P7S_UU).

(3) Social competences

A graduate of the specialization "Digital humanities" is capable of:

- recognizing her/his own knowledge necessary to do research and/or professional duties (P7S_KK);

- using experts' knowledge in digital humanities (P7S_KK);

- taking social responsibilities and initiating social projects connected with digital humanities (P7S_KO);

- following the ethical codex of information professionals (PS7_KR);

- sharing knowledge and skills in an open and friendly way (PS7_KR);

- cooperating with different groups of people engaged in digital humanities (PS7_KR).

\subsection{Discussion}

The concept of academic education of information professionals in digital humanities attempts to cover the main needs of digital humanities. Basic knowledge of digital humanities and relationships between digital humanities and information science will help students understand the meaning of their future work. It will also give them the knowledge where they could meet digital humanists and the place to work as well. The description of digital humanities shows that different disciplines of humanities make their research digital. Similarly to subject librarians, also information professionals need the basic knowledge of a particular humanities discipline to make humanities research digital in a more successful way.

Several abovementioned learning outcomes are related to particular fields of information science, i.e. information systems, digital collections, information architecture, information and knowledge organization, or user studies. Knowledge and skills in these areas are important to prepare research references such as digital collections, digital scholarly editions, databases with raw data, and citation databases for digital humanists. These types of research references were indicated in the description of digital humanities and the models of the research project lifecycle by Maron and Pickle (2014). Digital humanists build and use existing research references, therefore, the graduates of the specialization will have the broad knowledge on humanities digital collections and databases as well as competences to create necessary digital humanities research references.

Digital humanists work with digital data, namely, they find, collect, store, analyze, visualize, and share data according to the model of research project lifecycle by Sarretta (Minelli et al., 2018). If information professionals want to support digital humanists in research data management, they should gain the knowledge and skill in this field, too.

The description of digital humanities showed that most digital humanists prepared the results of their research in a multimedia way, which means that information professionals wanting to develop digital humanities need to have knowledge and skills in visualization and multimedia publications as well. They should also know the popular digital scholarly 
communication practices among digital humanists according to the Sarretta model of the research project lifecycle.

The description of digital humanities as well as the model of research project lifecycle by Maron and Pickle underline how crucial is research project management for digital humanists because a research project seems to be the most typical way to make humanities research digital. Therefore, the specialization graduates should be prepared to run projects in the digital humanities or to work as members of digital humanities projects teams.

Future information professionals could organize workshops, classes, and courses on digital humanities to teach current and future digital humanists for example, within academic courses in digital humanities offered by humanities faculties.

Openness to sharing knowledge, o teamwork, and participative projects, involving citizens and researchers are the significant features of digital humanities; it is important to encourage future information professionals developing digital humanities to follow this approach.

Some learning outcomes might look general and give impression that the concept of academic education of information professionals in digital humanities is similar to general information science academic courses. However, this learning outcomes focus on topics related to the digital humanities. For instance, within a course of information organization students will earn about data formats dedicated to humanities research references.

\section{Conclusions}

The main goal of the specialization discussed in this article is to give the graduates a basic knowledge in a particular humanities discipline as well as proficient information and computer skills necessary in digital humanities. This way, information professionals will be prepared to successfully cooperate with digital humanists.

Graduates of the specialization "Digital humanities" will acquire hard and soft skills. Hard skills will allow them to make humanities research digital thanks to the digitization of rare books or the creation of databases. Soft skills such as the ability to work in teams or project management, will be helpful to work with a project method, which is typically used in digital humanities.

Although some of abovementioned learning outcomes are frequently listed in the BA programs in information science, these learning outcomes will be trained and developed in a way that allows graduates to gain advanced skills in information science fields.

Faculties teaching future information professionals may consider cooperation with humanities and computer science departments to embed the specialization. The knowledge and skills of humanists and computer science specialists might be useful in teaching students effectively in other fields, not connected with information science.

The concept of a specialization "Digital humanities" encompasses the most important fields of knowledge and skills necessary for information professionals to work in digital humanities. The specialization responds to the needs of digital humanists in terms of support in information science-related issues. The concept of education of information professionals in digital humanities might be used to prepare a detailed program of the specialization by faculties teaching information science programs. It might also be used to adapt current university education programs in information science to the needs of digital humanities. 
Furthermore, some features of the presented specialization may support the concept of university education of information professionals in other disciplines where researchers apply new technologies to conduct their research. Digital humanists are not the only ones who need information professionals with advanced skills allowing to work in a digital information environment. After a proper modification, the concept of a specialization may be used to create university education for information professionals who want to work with researchers of social sciences, medicine, or life science who also apply new technologies in their research.

\section{References}

Hartsell-Gundy, A., Braunstein, L., Golomb, L., eds. (2015). Digital Humanities in the Library: Challenges and Opportunities for Subject Specialists. The Association of College \& Research Libraries, the American Library Association.

Kamińska, A. (2020). Cyfrowa humanistyka - koncepcja, kierunki i stan rozwoju oraz powiazania $z$ informatologia [doctoral thesis, University of Warsaw]. The University of Warsaw Repository, https://depotuw.ceon.pl/handle/item/3853

Lee, H. (2017). Is It Worth It? The Library and Information Science Degree in the Digital Humanities. In: S. Hai-Jew (ed.). Data Analytics in Digital Humanities. Multimedia Systems and Applications. Cham: Springer. https://doi.org/10.1007/978-3-319-54499-1_12

LIBER (2019). Europe's Digital Humanities Landscape - A Report from LIBER's Digital Humanities $\mathcal{E}$ Digital Cultural Heritage Working Group [online]. Ligue des Bibliothèques Européennes de Recherche - Association of European Research Libraries [20.08.2021], https://libereurope.eu/ blog/2019/06/21/dh-survey-2019/

Maron, N. L., Pickle, S. (2014). Sustaining the Digital Humanities: Host Institution Support Beyond the Start-up Phase. Ithata S+R. https://doi.org/10.18665/sr.22548

Millson-Martula, C., Gunn, K. (2017). The Digital Humanities: Implications for Librarians, Libraries, and Librarianship. College \& Undergraduate Libraries, 24(2-4), 135-139. https://doi.org/10.1080/ 10691316.2017.1387011

Minelli, A., Oggioni, A., Pugnetti, A., Sarretta, A., Bastianini, M., Bergami, C., Bernardi Aubry, F. (2018). The Project EcoNAOS: Vision and Practice Towards an Open Approach in the Northern Adriatic Sea Ecological Observatory. Research Ideas and Outcomes, 4(e24224). https://doi. org/10.3897/rio.4.e24224

MNSW (2018). Rozporzadzenie Ministra Nauki i Szkolnictwa Wyższego z dnia 14 listopada 2018 r. $w$ sprawie charakterystyk drugiego stopnia efektów uczenia się dla kwalifikacji na poziomach 6-8 Polskiej Ramy Kwalifikacji. Polska [online]. Ministerstwo Nauki i Szkolnictwa Wyższego [28.07.2021], http://isap.sejm.gov.pl/isap.nsf/DocDetails.xsp?id=WDU20180002218

Sula, C. A. (2013). Digital Humanities and Libraries: A Conceptual Model. Journal of Library Administration, 53(1), 10-26. https://doi.org/10.1080/01930826.2013.756680

White, J. W., Gilbert, H., eds. (2016). Laying the Foundation : Digital Humanities in Academic Libraries. West Lafayette: Purdue University Press. https://doi.org/10.2307/j.ctt163t7kq

Wilson E. A. (2020). Digital Humanities for Librarians. Lanham: Rowman \& Littlefield. 


\title{
Koncepcja akademickiego kształcenia specjalistów informacji w zakresie humanistyki cyfrowej
}

\begin{abstract}
Abstrakt
Cel/Teza: Celem artykułu jest przedstawienie autorskiej koncepcji akademickiego kształcenia specjalistów informacji w zakresie humanistyki cyfrowej.

Koncepcja/Metody badań: Koncepcję stworzono w oparciu o pogłębioną wiedzę na temat wybranych aspektów humanistyki cyfrowej oraz wybrane modele życia projektów badawczych. Koncepcja składa się z trzech elementów: opisów celów kształcenia, sylwetki absolwenta oraz zakładanych efektów kształcenia. Wyniki i wnioski: Koncepcja akademickiego kształcenia specjalistów informacji w zakresie humanistyki cyfrowej ma formę specjalizacji na studiach magisterskich. Podczas zajęć studenci zdobędą wiedzę w obszarze wybranej dyscypliny humanistycznej, teoretycznych aspektów humanistyki cyfrowej, jej organizacji oraz kontekstu powstania. Pogłębią swoją wiedzę i umiejętności na temat organizacji informacji i wiedzy, cyfrowych źródeł humanistycznych, systemów informacyjnych, bibliotek cyfrowych, zarządzania danymi badawczymi i publikacji tekstów naukowych. Absolwenci tej specjalizacji mogą znaleźć zatrudnienie w instytucjach naukowych rozwijających projektu z obszaru humanistyki cyfrowej lub dostarczających infrastrukturę badawczą dla humanistyki cyfrowej, np. w bibliotekach akademickich, muzeach, archiwach, centrach i laboratoriach humanistyki cyfrowej.

Zastosowania praktyczne: Koncepcja specjalizacji może być wykorzystana do stworzenia szczegółowych programów specjalizacji przez jednostki uczelniane prowadzące studia z zakresu nauki o informacji. Koncepcja uwzględnia polską specyfikę studiów wyższych, jednak może być z powodzeniem zaadaptowana w innych krajach, szczególnie w krajach UE, które, tak jak Polska, muszą przestrzegać Europejskich Ram Kwalifikacji.

Oryginalność/Wartość poznawcza: Kształcenie specjalistów informacji w obszarze humanistyki cyfrowej na poziomie studiów wyższych nie jest zbyt powszechne. Przedstawiona w artykule koncepcja kształcenia może pomóc w upowszechnieniu tego typu edukacji i tym samym przyczynić się do kształcenia nowych pokoleń bibliotekarzy oraz pozostałych specjalistów informacji jako wysoko wyspecjalizowanych mediatorów między humanistami a informacją.
\end{abstract}

\section{Słowa kluczowe}

Bibliotekarze. Humanistyka cyfrowa. Kształcenie akademickie. Nauka o informacji. Specjaliści informacji. Studia informacyjne.

ANNA KAMIŃSKA, PhD, is Assistant Professor at the Department of Information Studies, Faculty of Journalism, Information and Book Studies, University of Warsaw. She received her PhD degree in 2021 at the University of Warsaw. She did a research traineeship in the Laboratoire GERiiCO (University of Lille, France). Her main areas of interest include digital humanities, scholarly communication, data curation, and user studies. Her recent publications are: Jak biblioteki akademickie szkolą badaczy w zakresie otwartej nauki - na przykładzie kursu oferowanego przez Bibliotekę Uniwersytecką w Warszawie (2021, http://ebibojs.pl/index.php/ebib/article/ view/739), The Use of Information and Communication Technologies in Academic Libraries in a Crisis Situation (2020, co-authors: A. Książzak-Gronowska, Z. Wiorogórska, https://doi.org/10.36702/zin.704), Co mogą zaoferować cyfrowej humanistyce biblioteki i ośrodki informacji? (2017, https://doi.org/10.36702/zin.372).

Contact to the Author:

a.kaminska8@uw.edu.pl

Department of Information Studies

Faculty of Journalism, Information and Book Studies

University of Warsaw

Nowy Świat 69

00-046 Warszawa 